\title{
Orta Asya Türk Cumhuriyetleri ile Türkiye Arasında Sosyal Güvence İş Birliklerinin Değerlendirilmesi*
}

Mehmet Bulut ${ }^{* *}$

$0 \ddot{z}$

Uluslararası göçün göçmenler açısından ortaya çıkardığı en önemli sorunlardan birisi sosyal güvence konusudur. Nitekim ülkelerinden yurtdışına çalışmaya giden kişiler sosyal güvenlik mevzuatlarındaki katı kuralların etkisi ile ya tamamen sistem dışında kalmış ya da her iki ülke sisteminin de parçası olmuşlardır. Bu sorunun çözümlenmesi açısından ülkeler iç hukuk sistemlerinin yanında ikili sosyal güvenlik sözleşmelerini devreye sokmaktadırlar. Türkiye ile Orta Asya Türk Cumhuriyetleri arasında yaşanan insan hareketliliği de yıllar içinde kümülatif olarak artmıştır. Bunun sonucunda gerçekleşmesi gereken sosyal güvence iş birliği ise henüz yeterli seviyede değildir ve bazı adımların atılması gerekmektedir. Mevcut durumda Azerbaycan ve Kırgızistan ile onaylanmış olan ikili sosyal güvenlik sözleşmeleri bulunmaktadır. Ancak uygulama noktasında sıkıntılar yaşanmaktadır.

\section{Anahtar Kelimeler}

Sosyal güvenlik, ikili sosyal güvenlik sözleşmeleri, uluslararası göç, emeklilik, iş birliği, Orta Asya Türk Cumhuriyetleri.

- Geliş Tarihi: 26 Ağustos 2019 - Kabul Tarihi: 30 Nisan 2020

Bu makaleyi şu şekilde kaynak gösterebilirsiniz:

Bulut, Mehmet. "Orta Asya Türk Cumhuriyetleri ile Türkiye Arasında Sosyal Güvence İş Birliklerinin

Değerlendirilmesi." bilig, no. 99, 2021, ss. 85-113.

“" Doç. Dr., Bayburt Üniversitesi, İktisadi ve İdari Bilimler Fakültesi, Maliye Bölümü - Bayburt /

Türkiye

ORCID: 0000-0003-0157-4906

mehmetbulut@bayburt.edu.tr 


\section{Giriş}

Dünyamızda yaşanan bölgesel çıkar çatışmaları, iç ve dış savaşlar, doğal kaynakların yetersizliği, afetler, yaşam koşullarındaki zorluklar, istihdam olanaklarının azlığı, gelir dağılımında artan adaletsizlikler, hukuk devleti açısından yaşanan gerilemeler ve eğitim alanındaki kalitesizlik gibi birçok nedenle insanlar vatandaşı olduğu ülkeden başka ülkelere göç etmek zorunda kalmaktadırlar. Tarih boyunca yaşanan bu insan hareketleri bazen düzenli, bazen de düzensiz niteliktedir. Yaşanan göçler, geçici (ülkesine geri dönme niyetiyle yapılan) veya sürekli (ülkesine geri dönme niyeti bulunmayan) şekilde de olabilmektedir. Hatta göç edilen ülke açısından yasal veya yasadışı nitelikte de karşımıza çıkabilmektedir. Özellikle son birkaç yüzyılda Asya ve Afrika ülkelerinden Avrupa ülkelerine, Güney Amerika ülkelerinden ise Amerika Birleşik Devletleri ve Kanada gibi Kuzey Amerika ülkelerine yoğun bir göç dalgası gözlemlenmektedir.

Yaşanan uluslararası göçler, göç alan ülkeler açısından önemli ve telafisi zor sıkıntılar ortaya çıkartabildikleri gibi olumlu sonuçları da beraberinde getirebilmektedirler. Özellikle, işsizlik, düzensiz istihdam, kayıt dışlık, salgın hastalıklar başta olmak üzere sağlık problemleri, yasadışı sektörlerin büyümesi (fuhuş, insan kaçakçılığı, mafya gibi), eğitim problemleri, konut sorunu gibi konular uluslararası göç nedeniyle birçok ülkenin başını ağrıtmaktadır. Bu durum da ülkeleri uluslararası göçe karşı bazı radikal önlemler almaya itmektedir. Bunun yanı sıra nüfus sayısı ve nüfus artış oranı az olan ve/veya sosyal politika ve hukuki önlemler sayesinde göç eden kişilerin uyumunu hızlandırmada başarılı olan bazı gelişmiş ülkeler ise sorun gibi görünen göç olgusunu firsata çevirebilmektedir.

Göç edenler açısından bakıldığında ise en önemli tercih unsurunun, ekonomik ve sosyal açıdan daha rahat bir yaşam sürmek olduğunu söylemek yanlış olmayacaktır. Bu hedefe ulaşabilmek için ise insanlar ekonomik olarak gelişmiş ülkelerin yanı sıra çok gelişmiş olmasalar da kültürel adaptasyon sorunu yaşanmayacak ve/veya coğrafi olarak yakın ülkeleri tercih edebilmektedirler. Özellikle Türk Cumhuriyetlerinden Türkiye’ye yaşanan göçü ikinci kategoride değerlendirebiliriz.

Yaşanan uluslararası göçler nedeniyle ortaya çıkan sorunların tespiti ve çözüm yolları bulunması açısından ülkeler, uluslararası kuruluşlar ve akade- 
mik dünya birçok çalışmalar ortaya koymaktadır. Bunların başında işsizlikle mücadele, insana yakışır iş olanaklarının artırılması, sosyal adaptasyon, sağlık, kentleşme ve konut sorunlarının çözümü gelmektedir. Bunların dışında göç eden kişilerin sosyal güvenlik sorunları ayrı bir öneme sahiptir. Özellikle geçici nitelikte göç eden ve salt çalışma amacı olan kişileri ilgilendiren bu konu gerekli önlemlerin alınmaması halinde uzun vadede kişisel bazı hak kayıplarını beraberinde getirebilmektedir.

Son 20-30 yılda Orta Asya Türk Cumhuriyetlerinden Türkiye’ye önemli derecede göç gerçekleşmiştir. Bunun yanı sıra SSCB sonrası gelişme ve kalkınma sürecine giren bu ülkelere Türkiye'den nitelikli işgücü akışı da olmuştur. Çalışmamızda Orta Asya Türk Cumhuriyetleri ile Türkiye arasında yaşanan uluslararası göç çerçevesinde sosyal güvence iş birliğinin gerekliliği, ikili sosyal güvenlik sözleşmeleri ve gelinen nokta üzerinde durulacak ve değerlendirmelerde bulunulacaktır. Özellikle konunun Orta Asya Türk Cumhuriyetleri ve Türkiye ilişkileri özelinde akademik olarak yeterli çalışma olmaması sebebiyle çalışmamızın önemli bir boşluğu da dolduracağı düşünülmektedir.

\section{Uluslararası Göç ve Sosyal Güvenlik İliş̧kisi}

Göçler tarih boyunca insanlığın kaderini derinden etkilemiş bir olgudur. Öyle ki yaşanan göçler çağların kapanıp açılmasına vesile olmuştur. İnsanlar karşı karşıya kaldıkları iktisadi ve siyasi zorluklar, hak ihlalleri, afetler, salgın hastalıklar gibi nedenlerle kendi rızaları veya başkalarının baskıları ile anavatanlarını terk etmek zorunda kalmışlardır. Akabinde de geçici veya sürekli yaşamlarını sürdürebilecekleri daha güvenli yerlere sığınmışlardır. Tarih boyunca, varlığını giderek artan oranda sürdüren göç, günümüzde ulusal ve uluslararası alanlarda, özellikle de soğuk savaş döneminin sona ermesi ile daha da belirginleşmiş ve tüm toplumsal yaşamları, farklı biçimlerde de olsa, etkilemiş olan küreselleşme sonucunda; çok parçalı, çok taraflı ve karmaşık bir hal alarak evrensel bir sorun olmuştur (Çağlar 28).

Uluslararası göç olgusuna sadece bir sorun olarak bakmak ise doğru bir yaklaşım olmayacaktır. Aslında göç, mevcut olan bir soruna çare olarak insanlar tarafından üretilmiş bir çözümdür. Ayrıca uluslararası göç, bir arzın da karşılığıdır. Nitekim İkinci Dünya Savaşı sonrası dönemde işgücü arzını oluşturan göçmenlere Batı’nın talebi olmasaydı ekonomik anlamdaki göç hare- 
ketinin bu denli yoğun olması da imkânsız olurdu (A. Yılmaz 1694). Öyle ki uluslararası göç çoğu zaman ekonomik bunalımlardan çıkış noktasında göç alan ülkeler açısından bir çıkış yolu olmuştur. Bu nedenle göçün etkileri analiz edilirken olumlu ve olumsuz olarak çift yönlü yaklaşımda bulunmak daha doğru olacaktır.

Türk Dil Kurumu tarafindan göç, "ekonomik, toplumsal, siyasi sebeplerle bireylerin veya toplulukların bir ülkeden başka bir ülkeye, bir yerleşim yerinden başka bir yerleşim yerine gitme işi, taşınma, hicret, muhaceret" olarak tanımlanmıştır (TDK). Söz konusu hareketin ülkeler arasında gerçekleşmesi halinde karşımıza uluslararası göç (dış göç) kavramı çıkmaktadır. Göçler aynı zamanda daha alt sınıflandırmalara da tabi tutulabilmektedir. Örneğin; irade esasına göre (gönüllü ve zorunlu göçler), yoğunluk esasına göre (bireysel ve kitlesel göçler) ve yerleşme süreleri esasına göre (geçici ve sürekli göçler) ayrımlar yapılmaktadır (Yalçın 17). Bu sınıflandırmaya düzenli (yasal prosedürler dahilinde) ve düzensiz (yasa dışı) göç ayrımını da ekleyebiliriz. Nitekim 6458 sayılı Yabancılar ve Uluslararası Korumalar Kanunu'na göre; yabancıların, yasal yollarla Türkiye'ye girişini, Türkiye'de kalışını ve Türkiye'den çıkışını ifade eden göç düzenli göç; yabancıların yasa dışı yollarla Türkiye’ye girişini, Türkiye'de kalışını, Türkiye'den çıkışını ve Türkiye'de izinsiz çalışmasını ifade eden göç ise düzensiz göç olarak ifade edilmiştir. Devletler, genel olarak, düzensiz göçün 'yasadışlığını' vurgulayarak, bu durumu, topraklarına izinsiz giren, topraklarında izinsiz kalan ve çalışan insanların varlığını egemenlik haklarının bir ihlali olarak değerlendirme eğilimindedir ve bu nedenle, düzensiz göçe yönelik politikalarını anlatırken ağırlıklı olarak "mücadele” gibi sözcükler kullanmayı tercih etmektedirler (Özcan 29-30). Bununla birlikte başlangıçta düzensiz nitelikte olan bir göç hareketi tek taraflı veya ikili yaklaşımlarla düzenli (diğer bir deyişle yasal) hale getirilebilmektedir.

İnsanların göç etme sebeplerinin ortaya konulmasından göç veren ve göç alan ülkelerin itme/çekme faktörleri göz önünde bulundurulabilir. İtme ve çekme kuramı olarak adlandırılan bu yaklaşıma göre, hem yaşanan yerde hem de gidilecek yerde, itici ve çekici faktörler vardır ve hem itici hem de çekici faktörlerin birliği bir bütünlük oluşturmaktadır. Kuramın en önemli noktası yaşanılan yer ile göç edilecek yerdeki olumlu ve olumsuz faktörlerin birbirlerinden ayrı olarak değerlendirilmesi gerekliliğidir ve bu faktörler kişisel veya sosyal nitelikte olabilmektedir (Çağlayan 73). 
Göç kuramları açısından önemli bir yaklaşım ise göç sistemleri kuramıdır. Bu kuramda iki ya da daha fazla ülke karşıllklı olarak göçmen değişimiyle bir göç sistemi ve ilişkiler zinciri oluştururlar ve bu ilişki ve ilişkiler bütünü yakın iki ülke arasında gerçekleşebileceği gibi, birbirileriyle aralarında hayli mesafe bulunan ülkeler ve bölgeler arasında da kurulabilir (Çağlayan 82). Bir başka deyişle, tek taraflı veya karşılıklı olarak göç veren ve alan ülkeler, insan hareketliliğini belli kurallara bağlamak, vatandaşlarının haklarını korumak ve ileride meydana gelebilecek muhtemel sorunlar için şimdiden önlem almak amacıyla bir sistem kurma ve karşlıklı sözleşmeler imzalama yoluna gidebilmektedirler. Bir bakıma bu yaklaşımda ülkeler, göçü kontrol altına almak, göçmen yerleştirmeleri ile ekonomik ve hukuki ilişkileri kurallara bağlamak amacını güderler (Castles vd. 24). Günümüzde uluslararası ilişkilerin ve hareketliliğin hız kazanması nedeniyle göç sistemleri kuramı daha fazla önem kazanmış ve ülkeler ikili ilişkiler ve yaptıkları sözleşmelerle belirli kurallar belirlemişlerdir. Hatta uluslararası kuruluşlar genel sözleşmeler hazırlayarak ülkelerin iş birliği yapıp kurallara uymalarını sağlamaya çalışmışlardır. Uluslararası Çalışma Örgütü (ILO) ve hazırladığı sözleşmeler bu hususta örnek olarak gösterilebilir. Burada yukarıda da değindiğimiz gibi sadece uluslararası göçün kurallara bağlanması değil, düzensiz nitelikteki göçün düzenli (yasal) hale getirilmesi fonksiyonu da gerçekleşebilmektedir.

Bunun yanı sıra uluslararası ilişkilerden öte bazen ülkeler iç hukuk sistemlerinde yapacakları düzenlemeler ve çıartacakları kanunlar ile göçmenlerin haklarını koruma ve uyumlarını sağlama noktasında girişimlerde bulunabilmektedirler. Göçmenlerin göç ettikleri ülkelerde şiddet ve istismar gibi olumsuzluklara maruz kalmalarının önlenmesi, mültecilerin kültürel değerlerinin kaybolmaması (Zhanadilova 121) ve sosyal haklar sağlanması açısından bu tür uygulamalar önem arz etmektedir. Ayrıca uluslararası göç, günümüzde sadece düzenli göçmenleri, göçmen işçileri değil, aynı zamanda düzensiz göçmenleri ve milyonlarca sığınmacı ile mülteciyi de içermekte olup bu farklı gruplar kanunlar çerçevesinde farklı düzenlemelere tabii tutulmaktadırlar (Yıldız 42).

\section{Genel Olarak Sosyal Güvence Kavramı}

Devletin ve hukuk düzeninin korunması ve devamı bakımından sosyal sınıflar arasında barış ve dayanışmayı bozan ve toplumsal yapıyı tehdit eden bu tezatların giderilmesi gerekmektedir (Çubuk 9). Nitekim sosyal politika 
temelde eşitlik ilkesine dayanmaktadır. Sosyal politika, modern ve uygulanabilirlik anlamında insanların içinde bulundukları toplumlar içerisinde sağlık, güvenlik, barış ve refah içinde yaşamalarını hedef alan ve bu yollarla toplum grupları içindeki mücadeleleri önleyerek devlet düzenini ayakta tutmaya çalışan önlemler dizisi olarak ifade edilebilmektedir (Çubuk 12).

Sosyal güvence (veya sıkça kullanılan tabiriyle sosyal güvenlik) ise sosyal politika uygulamaları ve kişilerin karşı karşıya kalmış oldukları sosyal riskler nedeniyle ortaya çıkan bir olgudur. Bireyler yaşamları boyunca gelir kayıplarına uğramalarına yol açabilecek sosyal risklerle sık sık karşılaşabilmekte hatta bazen de vücut ve ruh sağlığı için çok büyük harcamalar yapmaktadırlar. Tarih boyunca aile içi yardımlaşma, bireysel tasarruf, dinsel yardımlar ve çevresel dayanışma gibi geleneksel koruma teknikleri ile sosyal güvenlik sağlanmaya çalışılmıştır. Zamanla toplumsal yapıda meydana gelen değişiklikler, aile içi dayanışmanın azalması gibi sebeplerden dolayı ülkemizde oldukça yaygın olan geleneksel koruma sistemi etkinliğini yitirmiştir. Bunun sonucunda, bireylerin kendilerinin ve ailelerinin karşılaşacakları sosyal tehlikeleri önlemek için bir güvence aramaları sosyal güvence kavramını doğurmuştur.

Sosyal güvence temelde, tehlikenin zararlarına karşı yürütülen mücadeleye verilen addır. Kişiyi, uğradığı zararlar dolayısıyla maruz kaldığı muhtaçlıktan, ihtiyaçlarının esiri olmaktan kurtarma mücadelesidir. Sosyal güvenlik, kişileri mesleki, fizyolojik ve sosyo ekonomik riskler dolayısıyla karşı karşıya kaldıkları tehlikelere ve zararlara karşı korumayı hedeflemektedir. Sosyal güvence, insanların kendilerini ve aile fertlerinin karşılaşacağı ve yaşamı için tehlike oluşturan olaylara karşı, güvence arayışının ürünüdür (Güzel vd. 2).

\section{Uluslararası Göç ve Sosyal Güvenlik}

Uluslararası göç, göç alan ülke ve göçmenler açısından bazı sorunları da beraberinde getirmektedir. Özellikle istihdam odaklı iktisadi sorunların yanı sıra kültürel ve sosyal sorunlar bunların başında gelmektedir. Bu tür sorunların en aza indirgenmesi noktasında göçmenlerin entegrasyonunun (uyumunun) sağlanması önem arz etmektedir. Entegrasyon, genelde göçmenlerin ana toplum ve değerlerini benimsemesi, içselleştirmesi ve gündelik yaşamına uyum süreci gibi algılansa da bunun yanında göçmenler ve ev sahibi toplumun karşılıklı olarak yapmaları gerekenleri tarif eden bir du- 
rumdur ve bir etkileşim söz konusudur (Çağlar 43). Göç olgusu, emek arzının önemli bir unsuru olup, artan göçle beraber göç alan veren ve transit ülke ayrımları belirsizleşmekte, düşük nitelikli işlerde kontrolsüz göçmen yoğunlaşması, iş koşullarının kötüleşmesine ve yerleşik nüfusta tepkiye neden olmaktadır (Strateji ve Bütçe Başkanlığı 7).

Entegrasyon kapsamında adım atan ülkeler genelde, vatandaşlık yerine uzun süreli oturum ve vatandaşlığa çok yakın haklar (istihdam piyasasında, sosyal güvenlik ve kamu hizmetlerinden faydalanmada eşitlik vb.) sunmak gibi düzenlemeler yapmayı tercih etmektedir (Yıldız 55). Göç alan ülke tarafından bu tür adımların atılmaması, sosyopolitik değeri olmadığı düşünülen bir gruba ait kişilere yönelik farklı ve eşitsiz uygulamalar (Yardım 125) anlamına gelen "ayrımcılık" olgusunun ortaya çıkmasına neden olmaktadır. Ayrıca son dönemlerde yaşanan göç hareketliliği Türkiye gibi ülkelerde işgücü piyasasında; işsizliğin artması, ücretlerin düşmesi ve kayıt dışı istihdamın artması gibi olumsuz etkiler doğurmaktadır (Nurdoğan ve Şahin 2215).

Göçün işsizlik, kayıt dışı istihdam, yoksulluk, yoksunluk, gecekondulaşma ve çevre sorunları gibi sonuçları sosyal politikanın alanına giren konulardır (Demir 72) ve burada karşımıza uluslararası koruma kavramı çımaktadır. Uluslararası koruma, kişinin vatandaşlık bağı ile bağlı olduğu devletin korumasından faydalanmasının mümkün olmadığı durumlarda gündeme gelmektedir (UNHCR 13). Bu kapsamda göç eden kişiler, geçici veya devamlı olarak yerleştikleri ülkelerde, spesifik amaçlar haricinde, iş bulmak ve çalışmak amacını gütmektedirler. Burada spesifik amaçlar derken, eğitim, tedavi, eşi çalışanlar için ev hanımlığı gibi durumları kastetmekteyiz. Amaç her ne olursa olsun göçmenler de ülke vatandaşları gibi sosyal risklerle karşı karşıya gelmektedirler. Söz konusu sosyal riskler, yaşlılık, malullük ve ölüm gibi uzun vadeli olabileceği gibi, hastalık, analık, iş kazası ve meslek hastalığı gibi kısa vadeli de olabilmektedir. Hatta bu sosyal risklere işsizliği de eklememiz mümkündür.

Göçmenlerin dışlanmışlık sorunu karşısında uluslararası düzenlemelerin yapılması gereği 1940'lı yıllarda gündeme gelmiş olup uluslararası iş birliği sağlanamadığı için ilk başlarda başarılı olunamamış ve uluslararası göçe iliş̧kin etkin düzenlemeler ancak Birleşmiş Milletler' in kurulmasından sonra yapılabilmiştir (Baştürk 354). Ayrıca sosyal güvenlik uluslararası düzeyde ilk defa 10.12.1948 tarihli İnsan Hakları Evrensel Bildirgesi'nde temel bir 
hak olarak düzenlenmiş ve bildirgenin 22'nci maddesinde “Her kişinin toplumun bir üyesi olarak, sosyal güvenlik hakkına sahip olduğu" belirtilmiştir. Uluslararası Çalışma Örgütü (ILO), 102 sayılı Sosyal Güvenliğin Asgari Normları Hakkında Sözleşme ile sosyal güvenliğe ilişkin asgari normları belirlemiştir. Sözleşmede sosyal güvenlik açısından başlıca şu dokuz risk sayılmıştır. Bunlar; hastalık halinde sağlık yardımı, hastalık halinde gelir kaybını karşılayan ödenekler, işsizlik, yaşlılık, iş kazası ve meslek hastalığı, analık, sakatlık, ölüm, aile yardımlarıdır. Sözleşmeyi imzalamak isteyen devletlere, bu risklerden en az üçüne karşı koruma sağlaması zorunluluğu getirilmiştir.

Sosyal güvenlik hakkı temel sosyal haklardan olup birçok ülkenin anayasasında da güvence altına alınmıştır. Nitekim Türkiye Cumhuriyeti Anayasası'nın 60. maddesine göre, "Herkes, sosyal güvenlik hakkına sahiptir. Devlet, bu güvenliği sağlayacak gerekli tedbirleri alır ve teşkilatı kurar." ifadesi yer almaktadır. Söz konusu madde hükmünde dikkat edilirse "Türkiye Cumhuriyeti vatandaşları" ibaresi kullanılmamış, "herkes" ibaresine yer verilmiştir. Dolayısıyla vatandaşlar dışında, ülkede yaşayan göçmenler de sosyal güvenlik hakkına sahiptir ve devletin bu hakkı kullandırmak için gerekli tedbirleri alması gerekmektedir. Bu durum sosyal devlet olmanın bir gereğidir. Ayrıca Anayasamızın "Yabancı Ülkelerde Çalışan Türk Vatandaşları" başlıklı 62. maddesinde devletin, yabancı ülkelerde çalışan Türk vatandaşlarının sosyal güvenliklerinin sağlanması için gereken tedbirleri alacağına ilişkin düzenlemeye yer verilmiştir.

ILO, 118 sayılı Muamele Eşitliği Sözleşmesi ile sosyal güvenlik hakkına uluslararası bir özellik kazandırmıştır. Bu sözleşmede, sözleşmeyi uygulayan her üye ülkenin, sözleşme mükellefiyetlerin kabul ettiği sosyal güvenlik dallarında, ülkesinde, bu sözleşmeyi uygulayan diğer üye devletler vatandaşlarına, sosyal güvenliğe tabi olma ve yardımlardan yararlanmaya hak kazanma bakımlarından, kendi vatandaşlarıyla ile eşit işlem yapması öngörülmüştür.

Sosyal güvenlik hakkının uluslararası bir nitelik kazanarak yabancılar için de uygulanıyor olması uluslararası insan hareketliliğine göç odaklı değil, göçmen odaklı yaklaşılmasını sağlamıştır. Bu durum da sosyal güvenliği uluslararası göç sorununun ayrılmaz bir parçası haline getirmektedir. Öyle ki göçmenlerin hastalanması, anne olmaları, çalışırken iş kazası geçirmeleri veya meslek hastalığına yakalanmaları halinde hangi haklara sahip olduklarını bilmeleri önem arz etmektedir. Ayrıca özellikle belli bir yaş sınırını 
geçtikten sonra göç eden kişilerin yaşlılık ve malullük sigortalarından faydalanma ve emekli olma koşulları da çok önemlidir. Göçmenler, yurt dışında çalıştıkları/bulundukları süreler için bulundukları ülkenin mevzuatına göre emeklilik hakkını elde etmelerinin yanı sıra, sosyal güvenlik sözleşmeleri veya borçlanma yapmak suretiyle ikinci bir emeklilik hakkı elde etmektedirler (Levent 316). Nitekim çoğu zaman, özellikle anavatanına geri dönme düşüncesinde olan göçmenlerin yabancı ülkede geçen çalışma sürelerinin emeklilik hesabında dikkate alınmasını sağlamaları gerekmektedir.

Yukarıda bahsettiğimiz hususlara ilişkin hak kayıplarının olmaması ve ILO'nun sıkça üzerinde durduğu insana yaraşır iş (decent work) amacına ulaşılması için uluslararası göç ve sosyal güvenlik bağlantısının güçlü şekilde kurulması ve gerek ulusal gerekse de uluslararası hukuki metinlerle bunların güvence alına alınması önemli bir sosyal devlet fonksiyonu olarak karşımıza çıkmaktadır.

\section{Türkiye ve Orta Asya Türk Cumhuriyetleri Arasında İlişkiler ve Göç}

1991 yılında SSCB'nin dağılmasından sonra Orta Asyåda bulunan Türk Cumhuriyetleri de bağımsızlıklarını ilan etmişler ve zaman içinde Türkiye ile önemli siyasi ve ekonomik ilişkiler içinde olmuşlardır. Aslında 1990’lı yılların başında ilişkilerin çok ileri düzeye taşınacağı ve hatta siyasi anlamda önemli adımların atılacağı ümit edilmekteydi. Nitekim, Orta Asya Türk Cumhuriyetleri'ni oluşturan nüfus kitlesinin ortak noktasının "Türklük" olması, nüfus potansiyelleri, eğitim seviyesinin yüksekliği, zengin yer altı kaynaklarının varlığı önemli bir avantaj ve değerlendirilmesi gereken bir potansiyel olarak nitelendiriliyordu (Akengin 10). Ancak, Türkiye'nin, Orta Asya Türk Cumhuriyetleri ile bağımsızlıklarının ilk dönemlerinde duygusal bir anlayışla geliştirmeye çalıştı̆̆ ekonomik ilişkiler beklendiği gibi çok önemli bir seviyeye gelememiştir (Bağırzade 47). 


\section{Tablo 1}

Türkiye'nin Türk Cumhuriyetleri ile Olan İhracat ve İthalat Verileri (Milyon $\mathrm{ABD} \$$ )

\begin{tabular}{ccccc}
\hline Yıl & İhracat & $\begin{array}{c}\text { Toplam İhracat } \\
\text { İçindeki Payı (\%) }\end{array}$ & İthalat & $\begin{array}{c}\text { Toplam İthalat } \\
\text { İçindeki Payı (\%) }\end{array}$ \\
\hline 2010 & 3.921 & 3,4 & 2.923 & 1,6 \\
2011 & 5.039 & 3,7 & 3.642 & 1,5 \\
2012 & 5.840 & 3,8 & 3.558 & 1,5 \\
2013 & 6.908 & 4,6 & 3.600 & 1,4 \\
2014 & 7.107 & 4,5 & 2.997 & 1,2 \\
2015 & 5.289 & 3,7 & 2.687 & 1,3 \\
2016 & 3.992 & 2,8 & 2.604 & 1,3 \\
2017 & 4.164 & 2,7 & 3.184 & 1,4 \\
2018 & 3.965 & 2,4 & 2.952 & 1,3 \\
\hline
\end{tabular}

Kaynak: TÜİK, Dış Ticaret İstatistikleri (2010-2018)

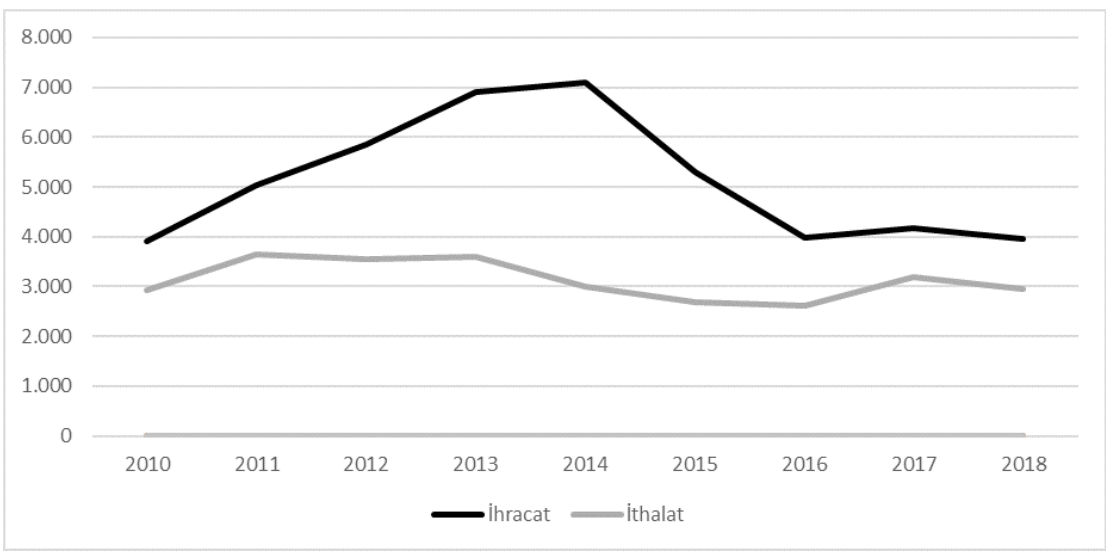

Grafik 1. Türkiye'nin Türk Cumhuriyetleri ile Olan İhracat ve İthalat Verileri (Milyon ABD \$) (TÜİK, Dış Ticaret İstatistikleri 2010-2018)

Yukarıda yer alan Tablo 1 ve Grafik 1'de Türkiye'nin Türk Cumhuriyetleri ile olan diş ticaret (ihracat ve ithalat) verileri gösterilmiştir. Türkiye ile Orta Asya Türk Cumhuriyetleri arasında 2010-2013 döneminde artış gösteren 
dış ticaret rakamları 2014 yılında petrol fiyatlarında yaşanan ciddi düşüşler ve Rusyåda yaşanan ekonomik kriz Türk Cumhuriyetlerini de etkilemiş, sabit döviz kuru sistemine tabi ülkelerde devalüasyon kararları alınmak zorunda kalınmış, serbest döviz kuru sistemine geçiş yapan ülkelerde ise döviz kurunda ciddi artışlar meydana gelmiş ve büyüme hızlarında düşüşler yaşanırken yüksek enflasyon rakamları görülmüştür (Doru ve Aslan 441). Yaşanan bu olaylar, Tablo 1 ve Grafik 1'de de görüldüğü üzere, 2014 yılından itibaren Türkiye ile Türk Cumhuriyetleri arasında hem ihracat hem de ithalat düşüşlerine neden olmuş, turizm ve doğrudan yatırımlar da olumsuz yönde etkilenmiştir. 2016 yılından sonra ise dış ticaret verileri yatay seyretmiştir.

Ayrıca ihracat ve ithalat rakamlarının toplam rakamlar içindeki payının da oldukça düşük seviyelerde bulunduğu görülmektedir. Türkiye’nin Türk Cumhuriyetleri ile olan ihracatın toplam ihracatına oranı 2013 yılında \% 4,6 seviyelerindeyken 2018 yllında bu oran \%2,4'e gerilemiştir. İthalatta ise yatay bir seyir söz konusu olup \%1,5 ila \%1,3 bandında seyretmiştir.

Türk Cumhuriyetlerinin yapmış oldukları ithalat miktarlarında ise Türkiye'nin payı 2001 yllında yaklaşık 496 bin dolar ile \%4 seviyelerinde iken 2017 yılında yaklaşık 4 milyar dolar ile \%6,7 seviyesine çıkmıştır. Buna rağmen söz konusu yükselişin yeterli seviyede olduğunu söylemek mümkün değildir (Doru ve Aslan 434). Türkiye'nin dış ticaret oranlarında bölge ülkeleriyle ilişkilerin istenilen seviyede gerçekleşmemesinin en önemli nedenleri ise Türk Cumhuriyetlerin, Azerbaycan dışında, coğrafi olarak uzak olması, ticari ilişkilerin üçüncü ülke topraklarını kullanarak yapılmak zorunda oluşu ve Türkiye'nin uluslararası ticaret hedeflerinin büyük oranda Avrupa Birliği yönünde olmasıdır (Balıkçıoğlu 243).

Orta Asya Türk Cumhuriyetleri açısından Türkiye'den en az ithalat yapan ülke Kazakistan olup beş ülkenin yapmış olduğu ithalatın yaklaşık yarısını yapan Kazakistan'ın Türkiye'den yapmış olduğu ithalat miktarı yaklaşık 730 bin dolar ile toplam ithalatı içindeki payı \%2,4 seviyelerinde kalmıştır (Doru ve Aslan 435). Ayrıca, Kazakistan'ın yurtdışındaki yatırımları ve yıllık toplam dış ticareti ile ilgili Kazakistan Merkez Bankası tarafından yayımlanan raporda, siyasi alanda belli bir düzeyde olan Kazak-Türk yakınlaşmasının ekonomiye yansımadığı görülmektedir. Öyle ki iki ülke ticaret ağının geliştirilmesi için alternatif projeler üretilmediği, insan ve mal taşımacılı̆̆ın çok 
pahalı olduğu, kültürel ilişkilerin gelişmesinin yetersiz kaldığı ve dolayısıyla tüm bunların hayal kırıklığı yarattığı görülmektedir (S. Yılmaz 826-830).

Türk cumhuriyetlerinden Türkiye'den en çok ithalat yapan ülkelerin ise Türkmenistan ve Azerbaycan olduğu görülmektedir. Türkmenistan 2017 yılı itibari ile Türkiye'den 1,03 milyar dolar ithalat yaparak toplam ithalatının yaklaşık \%23,7'sini Türkiye'den yapmışır. Azerbaycan'a en çok ihracat yapan ülkeler sıralamasında ise Türkiye yaklaşık 1,3 milyar ve \%14,6'lık pay ile ikinci sırada yer almıştır (Doru ve Aslan 435).

Türk Cumhuriyetleri arasında en fazla ticari ve kültürel ilişkinin kurulduğu Azerbaycan ise Türkiye'nin en önemli dış ticaret ortaklıklarından birisidir. İki ülke arasındaki ticaret hacmi genellikle artış sergilemiş, 1992 yılında yaklaşık 200 milyon dolardan, 2016 yılı sonu itibariyle yaklaşık 2,5 milyar dolara yükselmiştir. Ancak mevcut ikili ticaret hacmine olan ihtiyaç, potansiyelden düşük olup geliştirilmesi ihtiyacı her iki devletin yetkilileri tarafından vurgulanmaktadır (Aslanlı 23).

Türkiye ile Orta Asya Türk Cumhuriyetleri arasında gerçekleşen siyasi ve ticari ilişkiler zaman içinde insan hareketliliğine de neden olmuştur. Ayrıca ticari ilişkilerdeki inişli çıkışlı rakamların aksine özellikle Türk Cumhuriyetleri vatandaşlarının Türkiye'de yaşama sayısı kümülatif olarak artış göstermiştir.

Yıllardır göç olgusundan uzun süredir doğrudan veya dolaylı olarak etkilenen Türkiye özellikle Avrupa ülkelerine geçmek isteyen düzensiz göç yollarından biri olarak Asya ve Afrika kaynaklı göç hareketlerine maruz kalmış, diğer yandan son $4-5$ yıldır güney sınırındaki Suriye ve Irak'ta meydana gelen iç savaş nedeniyle yoğun bir şekilde sığınmacılara kapısını açmış ve bundan dolayı milyonlarca insan Türkiye'nin çeşitli kentlerine dağılarak merkezi yönetim ve yerel yönetim hizmetleri üzerinde ek yük oluşturmaktadır (Demirhan ve Aslan 57). Hiç kuşkusuz bu insan hareketi içinde Orta Asya Türk Cumhuriyetleri vatandaşları da yer almıştır. 


\section{Tablo 2}

Net Göç Oranları (2010-2015)

\begin{tabular}{cc}
\hline Ülke & Net Göç Oranı \\
\hline Türkiye & 4,3 \\
Kazakistan & 1,9 \\
Azerbaycan & 0,0 \\
Özbekistan & $-0,4$ \\
Türkmenistan & $-1,9$ \\
Kırgizistan & $-4,9$ \\
\hline
\end{tabular}

Net göç oranı; bir ülkeden göçen ve o ülkeye gelen göçmen sayısı arasındaki farkın, 1000 kişi başına ifade edilen ortalama nüfusa oranı ifade etmektedir. Kaynak: United Nations Development Programme 2018.

Türkiye ve Orta Asya Türk Cumhuriyetlerinin sahip oldukları göç potansiyelini gösteren net göç oranlarına baktığımızda (Tablo 2) Türkiye’nin 4,3’lük oranla göçmen sayısı fazla bir ülke olduğunu söylememiz mümkündür. Orta Asya Türk Cumhuriyetlerinde ise sadece Kazakistan'da net göç oranı pozitif olup Özbekistan, Türkmenistan ve Kırgızistan'ın göç veren ülkeler olduğunu görmekteyiz. Azerbaycan ise net göç oranında nötr durumda yer almaktadır.

\section{Tablo 3}

Vatandaşlık Ülkesine Göre Türkiye'ye Gelen ve Türkiye'den Giden Göç, 2017,2018

\begin{tabular}{lcccc}
\hline \multirow{2}{*}{ Ülke } & \multicolumn{2}{c}{ Türkiye'ye Gelen Göç } & \multicolumn{2}{c}{ Türkiye'den Giden Göç } \\
\cline { 2 - 5 } & $\mathbf{2 0 1 7}$ & $\mathbf{2 0 1 8}$ & $\mathbf{2 0 1 7}$ & $\mathbf{2 0 1 8}$ \\
\hline Türkmenistan & 20317 & 34915 & 4001 & 10096 \\
Azerbaycan & 20865 & 23245 & 10555 & 13804 \\
Özbekistan & 17871 & 15231 & 5528 & 13171 \\
Kurgızistan & 8982 & 9131 & 4596 & 7747 \\
Kazakistan & 4318 & 7395 & 3604 & 2453 \\
Toplam & 72353 & 89917 & 28284 & 47271 \\
\hline
\end{tabular}

Kaynak: TÜIKK, Uluslararası Göç İstatistikleri (2014-2018) 
Vatandaşlık ülkesine göre Türkiye'ye gelen ve Türkiye'den giden göç sayılarına baktığımızda (Tablo 3) Orta Asya Türk Cumhuriyetlerinden 2018 yılında 89.917 kişinin Türkiye’ye göç ettiğini görmekteyiz. 2018 yılında Türkiye'ye gelen yabancı uyruklu göçmen sayısının 466.890 olduğu göz önünde bulundurulduğunda \%19,2'lik bir oranla Orta Asya Türk Cumhuriyetlerinin önemli bir yere sahip olduğunu söyleyebiliriz (TÜİK 2014-2018). Aynı durum Türkiye'den giden göçte de söz konusu olup oran 2018 yılı için \%25,2 civarındadır. Türkiye ile Orta Asya Türk Cumhuriyetleri arasında gerçekleşen göçte Türkmenistan, Azerbaycan ve Özbekistan önemli paya sahip olup Kırgızistan ve Kazakistan için oranlar daha düşük seviyededir.

\section{Tablo 4}

Türkiye’de Yaşayan Türk Cumhuriyetleri Vatandaşı Nüfus (2018)

\begin{tabular}{lccc}
\hline \multicolumn{1}{c}{ Ülke } & Nüfus & $\begin{array}{c}\text { Yabancı Nüfustaki } \\
\text { Sıralaması }\end{array}$ & $\begin{array}{c}\text { Toplam Yabancı } \\
\text { Nüfus İçindeki Payı }\end{array}$ \\
\hline Türkmenistan & 68.146 & 6. & $\% 5,6$ \\
Azerbaycan & 61.807 & 7. & $\% 5,1$ \\
Özbekistan & 34.090 & 8. & $\% 2,8$ \\
Kırgızistan & 19.550 & 12. & $\% 1,6$ \\
Kazakistan & 16.828 & 15. & $\% 1,4$ \\
Toplam & 200.421 & & $\% 16,5$ \\
\hline
\end{tabular}

Kaynak: TÜİK, Uluslararası Göç İstatistikleri (2014-2018)

Türkiye'de yaşayan Türk Cumhuriyetleri vatandaşı nüfusa baktığımızda ise (Tablo 4) vatandaşlık ülkesine göre Türkiyesye gelen ve Türkiyesden giden göç sayılarına paralel oran ve sıralamalar görmekteyiz. Nitekim 2018 yılı itibariyle Türkiye'de yaşayan Orta Asya Türk Cumhuriyetleri vatandaşlarının toplam yabancı nüfusa oranı \%16,5 gibi yüksek bir orana sahiptir. Öyle ki tüm ülke vatandaşları içinde Türkmenistan uyruklular 6., Azerbaycan uyruklular 7. ve Özbekistan uyruklular 8. sıradadırlar.

2016 yılı veri alındığında ise Türkiye'de ikamet izni bulunan yabancılar açısından ilk on ülke arasında Azerbaycan üçüncü (39.184 kişi), Türkmenistan dördüncü (24.253 kişi) ve Özbekistan sekizinci (18.270 kişi) sırada yer almaktadır (Göç İdaresi Genel Müdürlüğü 39). Öğrenci ikamet izni açısından bakıldığında ise Azerbaycan birinci (10.528 kişi), Türkmenistan ikinci 
(6.600 kişi), Kazakistan sekizinci (1.428 kişi) ve Kırgızistan onuncu (1.360 kişi) sırada yer almaktadır (Göç İdaresi Genel Müdürlüğü 43).

\section{Tablo 5}

Uyruklara Göre Çalışma İzni Sayısı (2017)

\begin{tabular}{cc}
\hline Ülke & Çalı̧̧ma İzni Sayısı \\
\hline Azerbaycan & 2.449 \\
Kazakistan & 1.352 \\
Kırgizistan & 6.359 \\
Özbekistan & 2.465 \\
Türkmenistan & 3.847 \\
\hline
\end{tabular}

Kaynak: Aile, Çalışma ve Sosyal Hizmetler Bakanlığı, Çalışma Hayatı İstatistikleri-2017

Çalışma izni bulunan yabancılar açısından rakamlara bakıldığında ise 2017 yılında 6365 Kırgızistan vatandaşına ve 3.847 Türkmenistan vatandaşına çalışma izni verildiği görülmektedir. Bu ülkeleri Özbekistan, Azerbaycan ve Kazakistan takip etmektedir.

Çalışmamızın önceki başlıklarında da değindiğimiz gibi göçmen sınıflandırmasında en önemli olan hususlardan birisi düzenli ve düzensiz göçmen ayrımıdır. Türkiye'nin maruz kaldığı düzensiz göçmen sayısında 2015 yılında yaklaşık \%200’lük bir artış olmuştur ve 2016 yılında bu sayı 174 bin kişiyi geçmiştir. Bu sayı içinde Türk Cumhuriyetleri vatandaşlarının oranı ise oldukça azdır. Nitekim bu sayı Özbekistan vatandaşlarında 1.648, Azerbaycan vatandaşlarında ise 1.138 kişide kalmıştır (Göç İdaresi Genel Müdürlüğü 57-58).

Türkiye'de yasal olarak ikamet eden yabancıların göç etmek için Türkiye'yi tercih etmelerinin temel nedenleri arasında eğitim (yüzde 23), iş bulmak/ aramak (yüzde 19), güvenlik (yüzde 13) ve evlilik (yüzde 13) ön plana çımaktadır (Hacettepe Üniversitesi Nüfus Etütleri Enstitüsü 201). Türkiye'de yasal olarak ikamet etmekte olan Orta Asya uyruklu kişilerin Türkiye'yi tercih etmelerini sağlayan ve Türkiye'ye uyum süreçlerini kolaylaştıran önemli faktörlerden bir tanesi de Türkiye'de akrabalarının bulunmasıdır (Hacettepe Üniversitesi Nüfus Etütleri Enstitüsü 201). 


\section{İkili Sosyal Güvenlik Sözleşmeleri}

Zaman içinde daha fazla öneme sahip olan ve ülkeleri ortak politikalar oluşturmaya yönlendiren uluslararası göç olgusu, birçok farklı alanda uluslararası sözleşmelerin imzalanmasına neden olmuştur. Bu alanlardan birisi de sosyal güvenliktir. Nitekim sosyal güvenlik hakkının uluslararası bir nitelik kazanarak yabancılar için de uygulanıyor olması uluslararası insan hareketliliğine göç odaklı değil, göçmen odaklı yaklaşılmasını da sağlamıştır.

Ülkeler göçmenlerin yaşadıkları ekonomik, sosyal ve kültürel sorunlara çözüm bulurken ya da entegrasyonu hızla sağlamak isterken farklı yöntemler izleyebilmektedirler. Bu yöntemler bazen ülkenin iç hukuk sistemi vasıtasıyla hayata geçirilmekte iken bazen de uluslararası sözleşmelerle çözüm üretilmektedir. Sosyal güvenlik alanında da bu yöntemlerin her ikisiyle de karşılaşmak mümkündür. Türkiye açısından bakıldığında iç hukuk sistemi aracılı̆̆ıyla gerek ülkemizdeki yabancılar gerekse de yurtdışında bulunan gurbetçiler için yasal düzenlemelerin mevcut olduğunu görmekteyiz. Türkiye'de çalışan yabancıların Türkiye vatandaşları gibi sigortalı sayılması ve GSS hakkı (5510 SK, md 4 ve md 60); gurbetçiler için yurtdışı borçlanma imkânı (3201 SK) gibi düzenlemeleri örnek olarak sayabiliriz.

Ulusal hukuki kaynaklar dışında, yabancılar ve yurt dışındaki vatandaşlar hakkında sosyal güvenlik ile ilgili diğer bir kaynak ise ikili sosyal güvenlik sözleşmeleridir. Tarihi, çok taraflı sözleşmeler ve ulusüstü düzenlemelerden çok daha öncesine rastlayan ikili sosyal güvenlik sözleşmeleri, özellikle göçmen iş̧̧iliğin artması ile birlikte, ortaya çıkan sorunların çözümü için kuvvetli bir araç halini almıştır (Limoncuoğlu 2167).

Ülkeler arası insan hareketliliği sonucunda yabancıların göç ettikleri ülkelerde çalışma hayatına dâhil olmaları sosyal güvenlik açısından bazı sorunların ortaya çıkmasına neden olmuştur. Nitekim bazı ülkeler yabancılara negatif ayrımcılık uygulayarak sosyal güvenlik kapsamına almamışlardır. Bunun dışında bazı ülkeler sosyal güvence için mütekabiliyet şartını şart koşmuşlar veya zorunlu sigortalılık yerine isteğe bağlı sigortalılı̆̆ı öngörmüşlerdir. Ülkeler arasında ortaya çıkan söz konusu adaletsizlikleri gidermek amacıyla ikili sosyal güvenlik anlaşmaları yapılmaya başlanmıştır (Sözer 205). Kendi ülkesinden farklı bir ülkede çalışan, yaşayan insanların sosyal güvenlik sorunlarının çözümü, bu ülkelerde kazanacakları sosyal güvenlik haklarının 
kaybolmasının önlenmesi ve hatta tekrar kendi ülkelerine dönmelerinin sağlanması gibi hususlar ikili sosyal güvenlik sözleşmeleri ile çözülür (Arıcı 109).

Bununla birlikte, ikili sosyal güvenlik anlaşmalarının kapsamı coğrafi - kişisel ve maddi alan olmak üzere üç farklı kriterde belirlenmekte ve kapsamın sözleşmeden sözleşmeye birçok açıdan farklılık gösterdiği tespit edilebilmektedir (Limoncuoğlu 2186-2187). İkili sosyal güvenlik sözleşmeleri, uluslararası göçün yarattığı sorunlara çözüm bulması adına bazı ilkeleri bünyesinde barındırmaktadır. Bu ilkeler, mevzuatın tekliği ilkesi, eşit işlem görme ilkesi, kazanılmış hakların korunması ilkesi, yardımların transferi ilkesi ve koordinasyon ilkesidir (Levent 318).

İkili sosyal güvenlik sözleşme hükümlerinden faydalanacak kimselerin akit tarafların mevzuatı karşısında o ülkenin vatandaşları ile hak ve menfaatler bakımından eşit sayılması imkânı sağlanmaktadır ve böylece, sosyal güvenlik sözleşmesi yapılan ülkelerde çalışan vatandaşların bakmakla yükümlü oldukları aile bireyleri, sosyal güvenlik haklarından, çalışılan ülkenin vatandaşları gibi yararlanmaktadırlar (SGK, Sosyal Güvenlik). Ayrıca imzalanan sosyal güvenlik sözleşmeleri ile vatandaşlar, karşı ülkenin mevzuatından kaynaklanan kısa ve uzun vadeli sigorta kollarına ilişkin sosyal güvenlik haklarını kendi ülkelerinde kullanma imkânına sahip olmaktadırlar ve bu haktan tüm aile bireyleri faydalanabilmektedir (SGK, Sosyal Güvenlik).

İkili sosyal güvenlik sözleşmeleriyle, yurt dişındaki çalışmalarla mensubu bulunulan ülkedeki çalışmaların birleştirilerek, mensubu bulunulan ülkenin mevzuatına göre emekli aylığı bağlanması imkânı bulunmakta ve mensubu bulunulan ülkenin mevzuatına göre yurt dışındaki çalışmalar, vatandaşı olunan ülkede geçmiş gibi sayılarak, çalışmalar birleştirilip kişiye gerekli şartları sağlaması durumunda emekli aylığı bağlanmaktadır (Levent 322).

İkili sosyal güvenlik sözleşmelerinin bir başka işlevi ise yabancı kaçak iş̧̧i ve dolayısıyla kayıtdışı istihdam ile mücadelede etkin rol oynamasıdır. Nitekim göç edilen ülkedeki çalışmalarının vatandaşı olunan ülkede emeklilik noktasında dikkate alınacağının farkında olan kişi kayıtdışı çalışmaya direnç gösterebilecektir. Aksi halde yerel işgücü ile rekabet edebilmek adına kayıtdışı çalışmayı tercih edecektir. Öyle ki özellikle gelişmekte olan ve işgücü piyasası etkin olarak işlemeyen ülkelerde işverenler maliyetlerini azaltmak adına kayıtdışı çalışan yabancı iş̧̧ileri yerli iş̧̧ilere tercih edebilmektedir. Örneğin 
mevcut durumda Türkiye'deki Suriyeli, Afgan ve Iraklı göçmenler bu şekilde kayıt dışı çalıştırılmaktadır. Bu ülkelerle ikili sosyal güvenlik sözleşmelerinin olmaması bu sonucun ortaya çıkma sebeplerinden birisidir.

\section{Sosyal Güvence İş Birliğinde Mevcut Durum}

Ülkeler arasında imzalanan sosyal güvenlik sözleşmeleri ve dolayısıyla da sosyal güvence iş birliklerinin niteliği sahip olunan refah rejimlerine göre şekillenmektedir. Refah rejimi kavramı devlet, piyasa ve aile arasında bölüşülen refah üretimini ifade etmektedir ve liberal modelde, piyasanın ağırlığı; sosyal demokrat modelde devletin; muhafazakâr modelde ise ailenin baskın bir rolü bulunmaktadır (Ülgen vd. 638-639). Refah rejimlerine ilişkin bir diğer model ise Bismarck ve Beveridge yaklaşımlarına göre sosyal politikanın yürütülmesi ve finansmanın sağlanması açısından geliştirilmiş yaklaşımdır. Türkiyede refah rejimi ve dolayısıyla sosyal güvenliğin finansmanında Bismarck Yaklaşımı esas alınmıştır. Başka bir ifade ile sosyal güvenlik anayasal bir hak olmakla birlikte finansmanın sağlanması noktasında işçi ve işverenlerden alınan primler asli role sahiptir. Bununla birlikte Beveridge Yaklaşımı'nda da görüldügü üzere devlet katkısı ve bütçe transferi uygulamalarına yer verilmekte ve böylece sosyal güvenlik genel bütçeden finanse edilerek toplumsal bölüşüm sağlanmaktadır. Ayrıca son yıllarda özel sağlık sigortası ve bireysel emeklilik sistemi gibi piyasa yaklaşımına yönelik düzenlemeler güçlendirilmeye çalışılmaktadır. Orta Asya Türk Cumhuriyetleri'nde SSCB'nin dağılmasından sonra çağdaş sosyal güvenlik yaklaşımlarına yönelik düzenlemeler yapılmıştır. Bu doğrultuda öncelikle iş̧̧i ve işverenlerden toplanan primler ve akabinde de devlet katkısını esas kılan Türkiye uygulaması ile paralel düzenlemelere gidilmiştir. Bununla birlikte sağlık sisteminin finansmanı noktasında farklı uygulamalar göze çarpmakta olup tamamen genel bütçeden finansman yoluna gidilmektedir.

Türkiye 2020 yılı itibariyle otuz iki ülke ile ikili sosyal güvenlik sözleşmesi imzalamış bulunmaktadır. Orta Asya Türk Cumhuriyetleri açısından bakıldığında ise bu otuz iki ülke içinde sadece Azerbaycan ve Kırgızistan yer almaktadır. Azerbaycan ile yapılan ikili sosyal güvenlik sözleşmesi 17/07/1998 tarihinde imzalanmış ve 09/08/2001 tarihinde yürürlüğe girmiştir. Kırg1zistan ile ikili sosyal güvenlik sözleşmesi 09/04/2018 tarihinde imzalanmış olup 14/04/2020 tarih ve 31099 sayılı Resmi Gazete'de yayınlanan 7230 sayılı Kanun ile yürürlüğe girmiştir. 
Buna karşın Türkmenistan, Kazakistan ve Özbekistan ile Türkiye arasında imzalanmış ikili sosyal güvenlik sözleşmesi bulunmamaktadır. Ortak kültür, tarihsel geçmiş ve yukarıdaki başlıklarda değindiğimiz iktisadi ilişki ve uluslararası göç rakamları dikkate alındığında gelinen noktada sadece Azerbaycan ve Kırgızistan ile ikili sosyal güvenlik sözleşmesinin imzalanıp yürürlüğe girmiş olması önemli bir eksiklik olarak karşımıza çıkmaktadır. Nitekim Kırgızistan ile yapılan ikili sosyal güvenlik sözleşmesinin yürürlüğe girmesi için 2020 yılının Nisan ayına beklenilmiştir. Bu durum, gerek söz konusu ülkelerden Türkiye'ye gerekse de Türkiye'den bu ülkelere giden ve çalışma hayatına dahil olan kişiler açısından uzun vadede sosyal güvenlik sorunlarının ortaya çıkmasına neden olmuştur.

İkili sosyal güvenlik sözleşmelerinde önemli olan hususlardan birisi kapsamıdır. Buna göre sözleşmeler sigorta kolu ve sigortalılar açısından farklı kapsamlarda olabilmektedirler. Sosyal güvenlik, sigorta kolları açısından uzun vadeli ve kısa vadeli sigorta kolları olarak ikiye ayrılmaktadır. Uzun vadeli sigorta kollarına yaşlılık, malullük ve ölüm sigortaları, kısa vadeli sigorta kollarına ise sağlık yardımı sigortaları girmektedir. İkili sosyal güvenlik sözleşmeleri bu sigorta kollarının tümünü içerebileceği gibi birkaçını kapsama almış olabilir. Nitekim Türkiye'nin imzalamış olduğu sözleşmelerden çoğu sigorta kollarının tümünü kapsamına almıştır.

İkili sosyal güvenlik sözleşmelerinin sigortalılar açısından da kapsamı farklılık gösterebilmektedir. Buna göre sözleşmeler, hizmet akdine tabi çalışanlar, bağımsız çalışanlar ve devlet memurlarının tümünü kapsamına alabileceği gibi bunların birkaçını da kapsama alabilecektir. Örneğin Almanya, Belçika, İtalya, Macaristan ile yapılan sözleşmelerde bu kişilerin tümü kapsama alınmışken İngiltere ve Fransa ile yapılan sözleşmelerde sadece hizmet akdine tabi çalışanlar kapsama alınmıştır.

Türkiye ile Azerbaycan arasında imzalanan ikili sosyal güvenlik sözleşmesine kapsam açısından baktığımızda hem kısa vadeli hem de uzun vadeli sigorta kollarının kapsamda olduğunu, ancak Azerbaycan ile hastalık sigortasına ilişkin uygulamanın henüz yürürlüğe girmediğini görmekteyiz (SGK, Sosyal Güvenlik). Buna karşın uzun vadeli sigorta kolları hükümleri hizmet akdine tabi çalışanlar, bağımsız çalışanlar ve devlet memurlarının tümüne uygulanmaktadır. 
Türkiye ile Azerbaycan arasında yapılan sözleşmenin avantajlarından en önemlisi her iki ülke vatandaşlarının, hak ve menfaatler bakımından eşit işlem görmesidir. Bu anlamda, Türkiye'nin Azerbaycan'da çalışan vatandaşları ve bakmakla yükümlü oldukları aile bireyleri, sosyal güvenlik haklarından, Azerbaycan vatandaşları gibi yararlanma imkânına sahip olmuşlardır. Aynı durum Türkiye'de bulunan Azerbaycan vatandaşları için de geçerlidir.

Emeklilik yönünden, Türkiye ile Azerbaycan'da çalışmanın avantajlarından bir diğeri, ilgili ülkede geçen hizmetlerin diğeri tarafından tanınmasıdır. Sözleşmeye göre, ilgili ülkelerin mevzuatına göre geçen sigortalılık süreleri birbirinin devamı sayılmakta ve aylığa hak kazanılıp kazanılmadığının tespitinde, her iki ülkede geçen sigortalılık süreleri aynı zamana rastlamamak kaydıyla birleştirilmektedir. Bu şekilde aylığa hak kazanıldığında, aylık, her iki ülkede geçen çalışmalar birlikte dikkate alınarak hesaplanmaktadır. Nitekim Türkiye ve Azerbaycan, bu şekilde hesaplanan aylığın kendi ülkelerinde geçen çalışma gün sayısına isabet eden kısmını sözleşme aylığı (kısmi aylık) olarak ödemektedir.

Bir örnek vermek gerekirse, Türkiye'de 1800 gün ve Azerbaycan'da 4300 gün çalışması olan bir kişinin emekli olma talebi halinde aylığa hak kazanmasında bu sürelerin toplamı dikkate alınır ve kişinin 6100 gün çalışmasının olduğu kabul edilerek emeklilik işlemleri yapılır. Şayet kişi 6100 gün ile emekliliğe hak kazanıyorsa, sözleşmeye taraf her iki ülkede oransal olarak aylık hesabı yapılır.

Bununla birlikte eğer Türkiye ve Azerbaycan'da geçen sigortalılık süreleri, ülkelerin kendi mevzuatlarına göre, tam aylık bağlanmasına yeterli ise, hizmet birleştirmesi yapılmadan, her iki ülkeden de tam aylık bağlanabilmektedir. Bunun yanı sıra hizmet birleştirmesi yapılmadan doğrudan borçlanma yapmak ve bu suretle aylığa hak kazanmak da mümkündür.

Sosyal güvenlik sözleşmesi yapılan ülke mevzuatına göre yardım hakkının kazanılması şartlarının tespitinde, diğer ülkedeki ilk işe başlama tarihi de dikkate alınmaktadır. Diğer bir ifade ile sigortalının ilk defa Türkiye'de sigortalı olması halinde, sözleşme yapılan ülke açısından sigorta başlangıcı Türkiye'deki sigortalılık başlangıcı olduğu gibi tersi biçimde ilk defa sigorta başlangıcı sözleşme yapılan ülkede geçmiş ise Türkiye açısından da sigorta başlangıcı ilgili ülkedeki başlangıç kabul edilir (Kurt). Dolayısıyla bu Azer- 
baycan'daki sigortalılık sürelerini borçlananların, buradaki ilk işe başlama tarihi, Türkiye'de hiç çalışmaları yoksa veya bu tarih, Türkiye'deki sigorta başlangıç tarihinden daha önceye ait ise aylığa hak kazanmada Türkiye'de ilk işe giriş tarihi gibi kabul edilecektir (Gürel).

İkili sosyal güvenlik sözleşmelerin kapsamı belirlenirken özellikle kısa vadeli sigorta kolları bakımından daha çekinceli davranıldığı görülmektedir. Nitekim meslek hastalığı, geçici iş göremezlik gibi durumlarda ulusal mevzuat kapsamında kişilerin yardımdan faydalanmaya devam edebilmeleri için tedavi görmeleri şart koşulmuş olabilir. Çünkü hak sahibi kişinin yurt dışında bulunması veya çalışamadığı bu süreyi yurtdışında geçirmek istemesi halinde tedavi gördüğünün saptanması zorluk yaratacaktır. Ayni yardım içeren sigortalar bakımından da ayni yardımın o ülkede bulunmayan hak sahibine sağlanması çok zor olacaktır. Nitekim ülke tedavi imkanlarının aynı olmaması riski de bulunmaktadır (Limoncuoğlu 2184). Bu bağlamda Türkiye ve Azerbaycan imzalanan sözleşmede sağlık yardımlarına ilişkin hükümler bulunsa da henüz yürürlüğe konulması söz konusu olmamıştır. Bunun en önemli nedeni ise Azerbaycan'ın iç mevzuatlarından kaynaklanan nedenler ile sözleşmede yer alan sağlık sigortasına ilişkin hükümlerin uygulanma olanağı bulamamasıdır (SGK, Yurtdışındaki 8).

Ayrıca Türkiye ile Azerbaycan arasındaki sosyal güvenlik sözleşmesinde aile yardımlarının kapsama alınmış olması dikkat çekicidir ve Türk sosyal güvenlik sistemi içinde bulunmayan bu sigorta kolundan aslen Azerbaycan vatandaşları yararlanabilecektir (Yel 47).

Türkiye-Kırgızistan İkili Sosyal Güvenlik Sözleşmesi'nde ise hem kısa hem de uzun vadeli sigorta kolları kapsama alınmıştır. Ancak hizmet akdine bağlı olmaksızın kendi nam ve hesabına çalışanlar hastalık sigorta kolu, kamu görevlileri ise tüm kısa vadeli sigorta kollarının kapsamı dışında tutulmuştur. Burada önemli olan bir nokta ise Kırgızistan'ın ikili sosyal güvenlik sözleşmesi imzaladığı ilk ülkenin Türkiye olmasıdır (Orha Ajans).

Kırgızistan ile imzalanan ikili sosyal güvenlik sözleşmesi ile tarafların mevzuatında öngörülen sosyal güvenlik yardımlarına hak kazanılması için taraf devletlerde geçen sigortalılık sürelerinin birleştirilmesinin, çifte prim ödenmesinin önlenmesinin, aylık veya gelir almakta iken taraf devletlerde ikamet edenlerin aylık ve gelirlerinin yeni ikamet yerinde ödenebilmesinin 
amaçlandığı görülmektedir. Ayrıca anlaşma ile her iki akit taraf mevzuatına tabi olanların sosyal güvenlik haklarının mütekabiliyet esasları çerçevesinde korunmasının ve güvence altına alınmasının amaçlandığı, anlaşmanın yürürlüğe girmesiyle her iki akit taraf mevzuatına tabi olanların sosyal güvenlik hak ve yükümlülükleri bakamından eşit işlem görmeye başlayacağı, anlaşma ile tarafların mevzuatında öngörülen sosyal güvenlik yardımlarına hak kazanılması için akit taraf devletlerde geçen sigortalı hizmet sürelerinin birleştirilmesinin mümkün olacağı ve çalışanların hangi ülke mevzuatına tabi olacağının tespit edilerek bu sayede çifte prim ödenmesinin önüne geçileceği, her iki ülkede geçici görevli olarak çalışanların da iş kazası, meslek hastalığı sigortası ve uzun vade sigortalılı̆̆ kapsamında mütekabiliyet esasları çerçevesinde sigortalı sayılacakları öngörülmüştür.

\section{Sonuç}

Uluslararası göç tarih boyunca ülkeleri derinden etkilemiş ve önemli siyasi, kültürel, sosyal ve ekonomik sonuçların ortaya çıkmasına neden olmuştur. Söz konusu insan hareketliliğii, göç alan ülke ve göçmenler açısından bazı sorunları da beraberinde getirmiştir. Özellikle istihdam odaklı iktisadi sorunların yanı sıra kültürel ve sosyal sorunlar bunların başında gelmektedir. $\mathrm{Bu}$ tür sorunların en aza indirgenmesi ve göçmenlerin uyumunun sağlanması için ülkeler bazen kendi iç hukuk sistemlerinde düzenlemeler yapmışlar, bazen de uluslararası sözleşmelerle çözüm üretmişlerdir.

Sosyal güvenlik, sosyal politika uygulamaları ve kişilerin karşı karşıya kalmış oldukları sosyal riskler nedeniyle ortaya çıkan bir olgudur. Hastalık, yaşlılık, malullük gibi durumlarla karşılaşma riskine karşı bireylere güvence sağlama işlevi gören sosyal güvenlik, bu durumların meydana getirebileceği olumsuzlukları ve eşitsizlikleri gidermeye yönelik en etkili sosyal politika aracıdır. Sosyal güvenlik, kaynak ve gelirin yeniden dağıtımı yoluyla sosyal risklerin olumsuz sonuçlarını gidermeyi hedefler. Sosyal güvenliğin konusunu oluşturan riskler karşısında, bireylerin ihtiyaç duyduğu emniyet hissini sağlamak sosyal güvenliğin temel amacıdır. Riskler karşısında ekonomik güvensizlik ortamına itilen bireylere ekonomik güvence sağlama yoluyla bu emniyet ihtiyacı giderilir. Bu anlamda sosyal güvenlik uluslararası sözleşmelerde de yer alan evrensel bir ihtiyaç, bir insan hakkıdır. Sosyal güvenliğin amacı, çalışma gücünü, beden ve ruh sağlığını devam ettirmek için gelir kaynaklarını geçici ya da sürekli biçimde kaybedenlere toplum olarak yardım etmek suretiyle 
onları, gereksinimlerinin tutsaklığından kurtarmaktır. Risklerin iktisadi sonuçlarının yol açtığı gelir kaybı ve gider artışına karşı kişilerin güvenliğini sağlamak, dar anlamda yaptığımız sosyal güvenlik tanımı ile paralel olarak sosyal güvenliğin doğrudan amacıdır.

Ülkeler arasında yapılan ikili sosyal güvenlik sözleşmeleri, uluslararası göç nedeniyle ortaya çıkan sosyal güvence sorunlarının bertaraf edilmesi noktasında önemli bir role sahiptir. Özellikle göçmenlerin yerel vatandaşlarla eşit sosyal güvenlik haklarına sahip olmaları, uzun vadeli sigorta kolları açısından geçmişteki hizmetlerin zayi olmaması ve tekrar vatandaşı olan ülkeye dönmede teşvik edici olması ikili sosyal güvenlik sözleşmelerini gerekli kılmaktadır. Ayrıca bu sözleşmelerin örtülü olarak kayıt dışı istihdam ile mücadele fonksiyonu da bulunmaktadır.

Sovyetler Birliği’ nin 1991 yılında dağılmasından sonra bağımsız yeni Türk Cumhuriyetleri uluslararası arenada kendilerine yer bulmuşlardır. Türkiye bu ülkelerle tarihi ve kültürel ortak payda nedeniyle sürekli yakınlaşma gayreti içinde olmuştur. Nitekim ekonomik ilişkiler, 2015 yılından itibaren bir düşüş gösterse de canlılığını korumuştur. Ancak istenen seviyelerde olmadığını ve potansiyelinin çok daha yüksek olduğunu söylemek yanlış olmayacaktır. Öyle ki sürekli gündeme getirildiğinin aksine, Türk Cumhuriyetleri ile olan ekonomik ilişkiler Avrupa Birliği'ne alternatif oluşturabilecek düzeye erişebilmiş değildir (Aygün 15). Bununla birlikte, özellikle Orta Asya Türk Cumhuriyetleri'nden Türkiye'ye, zaman içerisinde önemli miktarda göç hareketi gerçekleşmiştir.

Orta Asya Türk Cumhuriyetleri ile Türkiye arasında yaşanan göç diğer uluslararası göçlerde olduğu gibi bazı sorunları ortaya çıkarmıştır. Bu sorunlardan sosyal güvence ile ilgili olarak atılan ortak adımlar ise ne yazık ki yetersiz seviyede kalmıştır. Mevcut durumda sadece Azerbaycan ve Kırgızistan ile onaylanmış ikili sosyal güvenlik sözleşmesi bulunmakta olup söz konusu sözleşmeler hem uzun hem de kısa vadeli sigorta kollarını kapsamaktadır. Ancak Azerbaycan özelinde ülke iç hukuk sistemlerinden kaynaklanan sorunlar nedeniyle kısa vadeli sigorta kolları hükümleri fiilen uygulanamamaktadır. Bununla birlikte Özbekistan, Türkmenistan ve Kazakistan ile henüz sosyal güvence iş birliği noktasında atılmış bir adım bulunmamaktadır. 
Bu çalışmamızla daha önceden akademik olarak yeteri kadar incelenmemiş olan hususlar ele alınmış ve dolayısıyla da Orta Asya Türk Cumhuriyetleri ve Türkiye arasındaki sosyal güvence iş birliklerine ilişkin mevcut durum ortaya konularak eksiklikler belirlenmeye çalışılmıştır. Özellikle yakın geçmişte gündeme gelen Türk dünyası vatandaşlığı projesi (Alyılmaz 77) kapsamında mümkün olduğunca sosyal, ekonomik, kültürel ve hukuki yakınlaşmanın hedeflendiği bir ortamda sosyal güvence noktasında yaşanan yetersizliğin giderilmesi noktasında adımların atılması, mağduriyetlerin giderilmesi açısindan önem arz etmektedir.

Özellikle Türkiye ile Orta Asya Türk Cumhuriyetleri arasında artan insan hareketliliği ile birlikte zaman içerisinde sosyal güvenliğe yönelik iş birliği eksiklikleri hissedilmeye başlanmıştır. Nitekim bir ülkede farklı ülkelerden göçmen işçi bulunduğunda, her ne kadar eşitlik ilkesini zedelese de, ülkede çalışan farklı vatandaşlığa sahip bu kişilerin farklı haklara sahip olması sonucu ortaya çıkmaktadır. Kısa süreli hareketliliklerde hastalık sigorta kolu kapsamında sağlanacak yardımların nitelik ve niceliklerinin belirlenmesinin yanı sıra göç kapsamında değerlendirilebilecek uzun süreli hareketliliklerde ise yaşlılık, malullük ve ölüm sigorta kollarında hak kayıplarının yaşanmaması açısından sosyal güvence iş birlikleri önemlidir. Bu açıdan Türkiye ile Orta Asya Türk Cumhuriyetleri arasında ikili sosyal güvenlik sözleşmelerinin yaygınlaştırılması ve iç hukuk sistemlerinin de sözleşmelerin uygulanmasını sağlayacak altyapıya kavuşturulması gerekmektedir. Türkiye’nin imzalamış olduğu ikili sosyal güvenlik anlaşmalarına bakıldığında uzun vadeli sigorta kollarının tüm sözleşmelerin kapsamında olduğu, kısa vadeli sigorta kolları bakımından ise daha sınırlı davranıldığı görülür.

Bu itibarla öncelikle Türkiye ile Orta Asya Türk Cumhuriyetleri arasında ekonomik iş birliklerinin geliştirilmesi, uluslararası göç ve turizm noktasında ortak kararların alınarak politikaların yürütülmesi, sosyal güvenlik bağlamında vatandaşların hak kayıplarının önlenmesi ve gelecekte telafisi zor durumların ortaya çıkmaması bakımından şimdiden gerekli adımların atılarak sosyal güvence iş birliklerinin gerçekleştirilmesi yerinde olacaktır. Sosyal güvence iş birliği açısından özellikle mevzuatsal altyapıların birbirleri ile uyumlu hale getirilmesine yönelik çabaların gösterilmesi de büyük öneme sahiptir ve bu bakımdan çalışma gruplarının oluşturulması ve uzman personel değişimi yapılması gerekmektedir. Nitekim mevcut durumda 
Azerbaycan ile yapılan ikili sosyal güvenlik sözleşmesinde, iç mevzuatlarından kaynaklanan nedenler ile sağlık sigortasına ilişkin hükümlerin uygulanma olanağı bulunmamaktadır. Bu sebeple sosyal güvence iş birliklerinde öncelikle iç mevzuatın uyumlaştırılması gerekmektedir.

\section{Kaynaklar}

Abrahamson, Peter. "The Welfare Modelling Business." Social Policy and Administration, vol. 33, no. 4, 1999, ss. 394-415.

Aile, Çalışma ve Sosyal Hizmetler Bakanlığı. Çalışma Hayatı İstatistikleri. Ankara, 2017.

Akengin, Hamza. "Türk Dünyası ve Orta Asya Türk Cumhuriyetleri Üzerine Jeopolitik Bir Değerlendirme." Mutad, vol. 4, no. 1, 2017, ss. 1-11.

Alyılmaz, Semra. "Türk Dünyası Vatandaşlı̆ıı Projesi." Uluslararası Türkçe Edebiyat Kültür Eğitim Dergisi, vol. 4, no. 1, 2015, ss. 77-85.

Arıcı, Kadir. Türk Sosyal Güvenlik Hukuku. Gazi Kitabevi, 2015.

Aslanl, Araz. "Türkiye-Azerbaycan Ekonomik İlişkileri." Yönetim ve Ekonomi, vol. 25, no. 1, 2018, ss. 15-27.

Aygün, Oğuzhan. "Türk Birliği, Avrupa Birliği' ne Alternatif Olabilir mi?? ECONDER, vol. 1, no. 1, 2017, ss. 35-52.

Bağırzade, Elşen Resuloğlu. "Türk Cumhuriyetleri Arasında Ticari İşbirliği: Mevcut Durum ve Perspektifler." Istanbul Journal of Sociological Studies, no. 41, 2011, ss. 41-60.

Balıkçığlu, Nevzat. "Türkiye İle Diğer Türk Cumhuriyetleri Arasında Dış Ticaretin Gelişimi: 2000-2017 Dönemi." CUJOSS, no. 1, 2019, ss. 225-245.

Baştürk, Şenol. Sosyal Politika, ed. Aysen Tokol ve Yusuf Alper, Dora Yayıncılık, 2014.

Castles, Stephen et al. The Age of Migration. Palgrave Mcmillan, 1998.

Çağlar, Türken. "Göç Çalışmaları İçin Kavramsal Bir Çerçeve." Toros Üniversitesi IIISBF Sosyal Bilimler Dergisi, vol. 5, no. 8, 2018, pp. 26-49.

Çağlayan, Savaş. "Göç Kuramları, Göç ve Göçmen İlişkisi." Muğla Üniversitesi Sosyal Bilimler Enstitüsü Dergisi (ILKE), no. 17, 2006, ss. 67-91.

Çubuk, Ali. Sosyal Politika ve Sosyal Güvenlik. Gazi Üniversitesi İ̈BF Yayınları, 1983.

Demir, Müslim. "Türkiye'de Yabanciların Sosyal Güvenliği." Sosyal Güvenlik Dergisi, vol. 6, no. 1, 2016, ss. 71-93.

Demirhan, Yılmaz, ve Seyfettin Aslan. "Türkiye'nin Sınır Ötesi Göç Politikaları ve Yönetimi.” Birey ve Toplum Dergisi, vol. 5, no. 9, 2015, ss. 23-62.

Doru, Ömer, ve Mehmet Barış Aslan. “Türkiye İle Türk Cumhuriyetleri Arasındaki Ekonomik İlişkiler: Dış Ticaret, Turizm ve Yatırım Açısından Bir Değerlendirme." Bingöl Üniversitesi Sosyal Bilimler Enstitüsü Dergisi, vol. 9, no. 17, 2019, ss. 427-442. 
Göç İdaresi Genel Müdürlüğü. 2016 Türkiye Göç Raporu. Ankara, 2016.

Gürel, Begüm. "Yurtdışında Geçen Sürelerin Sosyal Güvenlik Bakımından Değerlendirilmesi.” Hukuki Haber, 23 Ağustos 2019, https://www.hukukihaber. net/yurtdisinda-gecen-surelerin-sosyal-guvenlik-bakimindan-degerlendirilmesi-makale,6046.html.

Güzel, Ali vd. Sosyal Güvenlik Hukuku. Beta Yayınevi, 2003.

Hacettepe Üniversitesi Nüfus Etütleri Enstitüsü. Türkiye'de Yasal Olarak İkamet Eden Yabancıların Profili ve Yaşam Koşulları. 2017.

Kurt, Resul. "İki Ülkede Geçen Sigortalılık Sürelerinin Birleştirilmesi.” Dünya Gazetesi, 14 Mart 2014.

Levent, Recep. "Yurt Dışında Çalışan veya Bulunanlar ile Göçmenlerin Sosyal Güvenliği." TBB Dergisi, no.116, 2016, ss. 315-334.

Limoncuoğlu, Siyami Alp. "İkili Sosyal Güvenlik Anlaşmalarının Kapsamı.” D.E.Ü. Hukuk Fakültesi Dergisi, no. 19, 2017, ss. 2165-2191.

Nurdoğan, Ali Kemal, ve Menekşe Şahin. "Türkiye’ye Yönelen Uluslararası Göç İşsizliğin Bir Nedeni mi?” OPUS Uluslararası Toplum Araştırmaları Dergisi, vol. 11, no. 18, 2019, ss. 2201-2223.

Orha Ajans (2018). "Kırgızistan-Türkiye Sosyal Güvenlik Anlaşması Nasıl Uygulanacak?” Orha Ajans, 24 Ağustos 2019, https://orhaajans.com/kirgizistan-turkiye-sosyal-guvenlik-anlasmasi-nasil-uygulanacak.

Özcan, Nazlı Şenses. "Düzensiz Göç Üzerine Bir İnceleme: Küresel Dinamikler, Ulus-Devletler, Göçmenler.” İdeal Kent Dergisi, no. 15, 2015, ss. 22-39.

SGK. Yurtdışındaki Vatandaşların Sosyal Güvenlik Hakları ve Yurtdışı Borçlanma. Ankara, 2013.

SGK. Sosyal Güvenlik Sözleşmeleri. Ankara, 2019.

Sözer, Ali Nazım. "İkili Anlaşmalarla Sosyal Hukukun Koordinasyonu.” Legal $\dot{I}_{3}$ Hukuku ve Sosyal Güvenlik Hukuku Dergisi, no. 5, 2005, ss. 203-221.

Strateji ve Bütçe Başkanlığı. Onbirinci Kalkınma Planı. 2019.

Şenkal, Abdulkadir vd. "Avrupa Birliği'nin Karşılaştırmalı Refah Modelleri ve Sosyal Politikada Devletin Değişen Rolü.” Kocaeli Üniversitesi Sosyal Bilimler Enstitüsü Dergisi, vol. 14, no. 2, 2007, ss. 146-175.

TÜİK. “Dış Ticaret İstatistikleri (2010-2018).” 21 Ağustos 2019, http://www.tuik. gov.tr/PreTablo.do? alt_id=1046.

TÜİK. “Adrese Dayalı Nüfus Kayıt İstatistikleri (2014-2018).” 21 Ağustos 2019, http://www.tuik.gov.tr/ PreTablo.do?alt_id=1059.

TÜİK. “Uluslararası Göç İstatistikleri (2017-2018).” 21 Ağustos 2019, http:// www.tuik.gov.tr/PreTablo.do? alt_id=1067.

Türk Dil Kurumu (TDK). Güncel Türkçe Sözlük. http://sozluk.gov.tr.

UNHCR. UNHCR Master Glossary of Terms. Rev.1. Cenevre, 2006. 
United Nations Development Programme. Human Development Indices and Indicators. 2018.

Ülgen, Gülden vd. "Refah Rejimleri Sınıflandırma Çalışmaları: Cinsiyet Boyutları.” Marmara Üniversitesi İktisadi ve İdari Bilimler Dergisi, vol. 39, no. 2, 2017, ss. 637-656.

Yalçın, Cemal. Gö̧̧ Sosyolojisi. Anı Yayınları, 2004.

Yardım, Müşerref. "Göç ve Entegrasyon Politikaları Işı̆̆ında Fransa'da Toplumsal Kabul.” Göç Araştırmaları Dergisi, vol. 3, no. 2, 2017, ss. 100-136.

Yel, Aytül. Taraf Olduğumuz İkili Sosyal Güvenlik Sözleşme Uygulamalarında Yaşanan Olumsuzlukların Analizi ve Çözüm Önerileri. Sosyal Güvenlik Uzmanlığg Tezi, 2013.

Yıldız, Ayselin. "Göç ve Entegrasyon Politikalarında Vatandaşlık.” Göç Araştırmaları Dergisi, vol. 3, no. 1, 2017, ss. 36-67.

Yılmaz, Abdurrahman. "Uluslararası Göç: Çeşitleri, Nedenleri ve Etkileri." Turkish Studies International Periodical For the Languages, Literature and History of Turkish or Turkic, vol. 9, no. 2, 2014, ss. 1684-1704.

Yılmaz, Serdar. "Kazakistan-Türkiye Ekonomik ve Kültürel İlişkileri: Vaatler ve Gerçekler.” Insan ve Toplum Bilimleri Araștırmaları Dergisi, vol. 6, no. 2, 2017, ss. 813-834.

Zhanadilova, Aigul. "Farklı Kuramlar Çerçevesinde Uluslararası Göç Sorunu.” $M u$ hakeme Dergisi, vol. 1, no. 2, 2018, ss. 116-122. 


\title{
Evaluation of Social Security Cooperation between Turkey and Central Asian Turkish Republics*
}

Mehmet Bulut $^{* *}$

\begin{abstract}
One of the most important problems of international migration for immigrants is the issue of social security. As a matter of fact, the people who went to work abroad from their countries either remained completely out of the system or became a part of both countries with the effect of strict rules in social security legislation. In order to solve this problem, countries are introducing bilateral social security agreements as well as domestic legal systems. The human mobility occurred between the Central Asian Turkish Republics and Turkey have increased cumulatively at over the years. As a result of this, the social security cooperation to be realized is not yet sufficient and necessary steps should be taken. Currently, there are bilateral social security agreements that have been ratified with Azerbaijan and Kyrgyzstan. However, there are problems at the point of application.
\end{abstract}

\section{Keywords}

Social security, bilateral social security agreements, international migration, pension, cooperation, Central Asian Turkish Republics.

\footnotetext{
Date of Arrival: 26 August 2019 - Date of Acceptance: 30 April 2020

You can refer to this article as follows:

Bulut, Mehmet. "Orta Asya Türk Cumhuriyetleri ile Türkiye Arasında Sosyal Güvence İş Birliklerinin Değerlendirilmesi." bilig, no. 99, 2021, pp. 85-113.

"* Assoc. Prof. Dr, Bayburt University, Faculty of Economics and Administrative Sciences, Department of Finance - Bayburt / Turkey ORCID: 0000-0003-0157-4906

mehmetbulut@bayburt.edu.tr
} 


\title{
Сотрудничество в области социального обеспечения между Турцией и тюркскими республиками Центральной Азии
}

\section{Мехмет Булут ${ }^{*}$}

\begin{abstract}
Аннотация
Одной из важнейших проблем международной миграции является вопрос социального обеспечения. Фактически, люди, которые уехали из своих стран на заработки за границу, либо остались полностью вне системы, либо стали частью обеих стран с эффектом строгих правил в законодательстве о социальном обеспечении. Для решения этой проблемы страны вводят двусторонние соглашения о социальном обеспечении, а также национальные правовые системы. Мобильность людей между тюркскими республиками Центральной Азии и Турцией в совокупности увеличилась на протяжении многих лет. В результате этого сотрудничества в области социального обеспечения еще недостаточно, и необходимо предпринять определенные шаги. В настоящее время существуют двусторонние соглашения о социальном обеспечении, ратифицированные с Азербайджаном и Кыргызстаном. Однако есть проблемы с применением.
\end{abstract}

\section{Ключевые слова}

Социальное обеспечение, двусторонние соглашения о социальном обеспечении, международная миграция, пенсия, сотрудничество, тюркские государства Средней Азии.

\footnotetext{
Поступило в редакцию: 26 августа 2019 г. - Принято в номер: 30 апреля 2020 г. Ссылка на статью:

Bulut, Mehmet. "Orta Asya Türk Cumhuriyetleri ile Türkiye Arasında Sosyal Güvence İş Birliklerinin Değerlendirilmesi." bilig, no. 99, 2021, pp. 85-113.

** Доц., д-р, Байбуртский университет, факультет экономики и управления, кафедра финансов - Байбурт / Турция ORCID: 0000-0003-0157-4906 mehmetbulut@bayburt.edu.tr
} 
